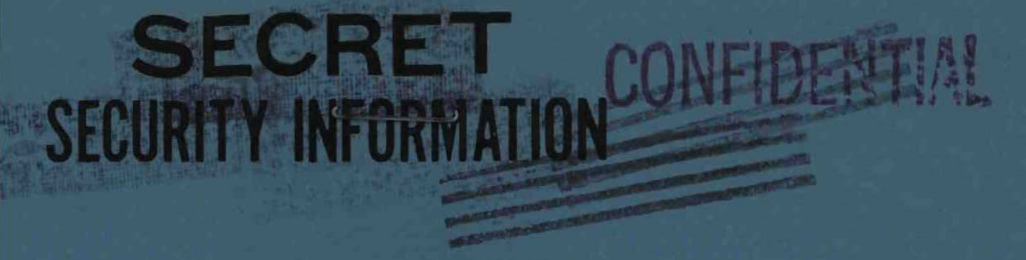

\title{
URANIUM EXTRACTION WITH \\ TRIBUTYL PHOSPHATE IN A \\ PULSE COLUMN
}

\author{
AUTHORS: \\ K. Kniel (Leader) \\ C. L. Gregory \\ E. R. Renier \\ R. H. Reuther
}

MASSACHUSETTS INSTITUTE OF TECHNOLOGY Engineering Practice School

\author{
Engineering Practice School \\ Prepared From Work Performed Under Subcontract 70 \\ With The \\ CARBIDE AND CARBON CHEMICALS COMPANY \\ A Division of Union Carbide and Carbon Corporation \\ Oak Ridge, Tennessee
}

\section{RESTRICTED DATA}

This document contains restricted data as defined in the Atomic Energy Act of 1946. Its transmittal or the disclosure of its contents in any manner to an unauthorized person is prohibited.

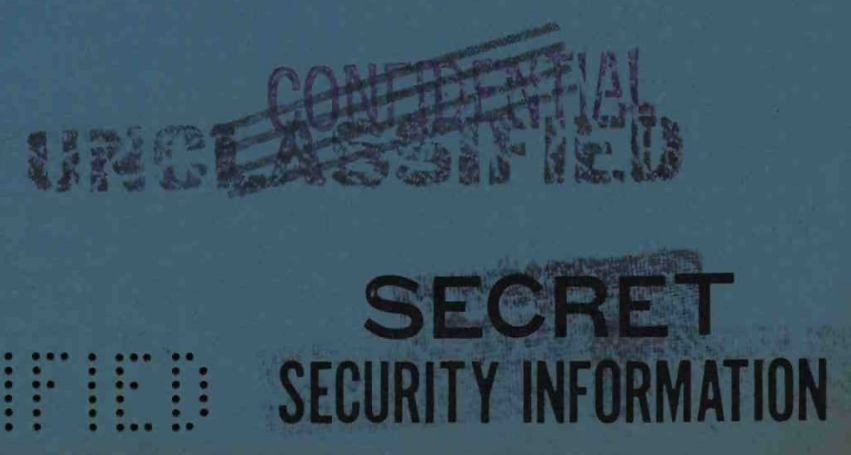




\section{DISCLAIMER}

Portions of this document may be illegible in electronic image products. Images are produced from the best available original document. 
Approved for tssue: H. T. Tupper

Dote of Issue: April 7, 1952
Report Number:

File Number:

$\mathrm{K}-903$

File Numbor:

EPS-Y 148

Subject Category: PROCESSES FOR PLUTONIUY

URANIUM EXTRACTION WITH TRIBUTYL PHOSPHATE IN A PUISE COLUNN

By

K. Kniel (leader), C. L. Gregory, E. R. Renier, R. H. Reuther

\section{LEGAL NOTICE}

This report was prepared as an account of Government sponsored work. Noither the United States, nor the Commission, nor any person acting on behalf of the Commission:

A. Makes any worranty or representotion, express or implied, with respect to the accuracy, completeness, or usefulness of the information contained in this report, or that the use of any information, apparatus, method, or process disclosed in this report moy not infringe privately owned rights; or

B. Assumes any liabilities with respect to the use of, or for damoges resulting from the use of any information, apparatus, method, or process disclosed in this report.

As used in the above, "person acting on behalf of the Commission" includes any employee or contractor of the Commission to the extent that such employee or contractor prepares, handles or distributes, or provides access to, any information pursuant to his employment or contract with the Commission.

CLASSIFICATION CANCELLED
DATE $\quad$ FEB 231957

For The Atomic Energy Commission

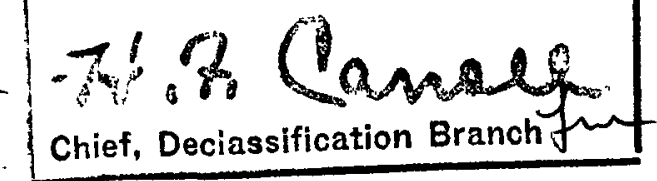

$$
\because \because \quad \% 91
$$

\section{MASSACHUSETTS INSTITUTE OF TECHNOLOGY} Engineering Practice School

Propared from work performed at the Y-12 Plant of the

CARBIDE AND CARBON CHEMICALS DIVISION

Union Carbide and Carbon Corporation

Oak Ridge, Tonnessee

Subcontract 70
Photostat Price $\$ 6.30$ Microfilm Price $\$$

Available from the

Office of Technical Services

Department of Commerce

Washington 25, D. C. 


Report Number: $\frac{\mathrm{K}-903}{\mathrm{EPS}-\mathrm{Y} 148}$
File Number:
Date of Issue: $\frac{\text { April 7, } 1952}{}$

Title: Uranium Extraction with Tributyl Phosphate in a Pulse Colum

Authors: K. Kniel (leader), C. L. Gregory E. R. Renier, R. H. Reuther

\section{MASSACHUSETTS INSTITUTE OF TECHNOIOGY \\ Engineering Practice School}

\section{ABSTRACT}

The effect of variation in T.B.P. concentration in Varsol upon uranium extraction in a pulse column was studied. Values of H.T.U.OE for an aqueous feed containing urangl nitrate, nitric acid, and sodium nitrate were obtained for a constant volume ratio of pure T.B.P. to aqueous flow rate. The concentration of T.B.P. in Varsol was varied from 5 to 30 volume percent. The value of H.T.U.OE ranged from $9 \mathrm{ft}$. to $13.5 \mathrm{ft}$. and decreased with increasing values of percent T.B.P. This is explained on the basis of a decrease in organic flow rate with increasing percent T.B.P.

Nitric acid was found to be extracted into the organic phase at the bottom of the column and to be stripped from the organic phase into the aqueous phase at the top of the column. Equilibrium and operating lines are presented for nitric acid extraction. 
TABLE OF CONTENTS

$\underline{\text { Page }}$

I. ABSTRACT

II. SUMMARY

7

III. INTRODUCTION 8

IV. PROCEDURE 9

V. RESULTS

A. URANIUM TRANSFER DATA 12

B. NITRIC ACID TRANSFER DATA 18

VI. DISCUSSION OF RESULTS

A. URANIUM EXXTRACTION 21

B. EQUILIBRIUM DATA 22

C. NITRIC ACID EXTRACTION 23

VII. CONCLUSIONS 24

VIII. RECOMMENDATIONS 24

IX. APPENDIX

A. SUMMARY OF DATA AND GALCULATED VALUES 25

B. DETERM INATION OF DISTRIBUTION COEFFICIENTS 29 (METHODS OF ANALYSIS)

C. ESTIMATION OF EQUILIBRIUM LINE FOR NITRIC ACID 30 TRANSFER

D. TABLE OF NOMENCLATURE

E. LITERATURE CITATIONS 35

F. ACKNOWLEDGEMENTS 35

G. IOCATION OF ORIGINAL DATA 


\section{SUMMARY}

The effect of variation in T.B.P. (Tributyl phosphate) concentration upon the uranium extraction in a pulse column has been studied.

The aqueous feed composition was $10 \mathrm{~g} \cdot / \mathrm{l}$. U $\left[\mathrm{as} \mathrm{VO}_{2}\left(\mathrm{NO}_{3}\right)_{2}\right], 1 \mathrm{M} \mathrm{HNO}_{3}$, and $3.4 \mathrm{M} \mathrm{NaNO}$. The aqueous feed rate was held constant at $475 \mathrm{ml} . / \mathrm{min}$. (except during the last run when it was $160 \mathrm{ml} . / \mathrm{min}$.) and a 5/8-in pulse was impressed upon the column at a frequency of $50 \mathrm{cycles} / \mathrm{min}$. The ratio of pure T.B.P. to aqueous flow rate on a volume basis was 0.06 . Volume percent T.B.P. in Varsol was varied from 5 to 30 , in increments of $5 \%$.

Sample taps were installed at three points within the column. These taps enabled sampling and analysis of both streams in the column. In this way five points on an operating line for the column could be determined.

Values for H.T.U.OE for uranium extraction were found to increase with increasing percent T.B.P. This appears to be the result of the fact that the organic flow rate into the pulse column was decreased with increasing percent T.B.P. in order to maintain the flow ratio mentioned above. The smallest value found for H.T.U.OE was $9 \mathrm{ft}$., and the largest was $13.5 \mathrm{ft}$. Nitric acid was found to be extracted from the aqueous phase at the bottom of the column and to be stripped from the organic phase at the top. An equilibrium curve and an operating line for nitric acid during a typical run are presented.

Additional data are needed in order to evaluate the effect of T.B.P. concentration upon uranium extraction over a wider range of flow rates and flow ratios. Also, throughput capacity should be investigated. 


\section{INTRODUCTION}

The uranium in aqueous waste solutions is currently recovered at $Y-12$ by solvent extraction, using dibutyl carbitol as the organic solvent. An alternate solvent, also having the selective action necessary for uranium recovery, is a mixture of tributyl phosphate (T.B.P.) and some hydrocarbon diluent.

The aqueous feed for an extraction process using T.B.P. usually contains inorganic salts, nitric acid and uranyl nitrate. The organic phase extracts the uranyl nitrate because of the formation or a uranyl nitrate-T.B.P. complex, which has the formula $\mathrm{UO}_{2}\left(\mathrm{NO}_{3}\right)_{2}\left(\mathrm{~T} . \mathrm{B} \cdot \mathrm{P}_{\mathrm{O}}\right)_{2}(4)$. The concentration and kind of inorganic salts in the aqueous phase and the concentrations of nitric acid and uranium have an effect upon the distribution coefficient for the uranium. The salts are not extracted the organic phase, but the nitric acid is. The distribution coefficient for the nitric acid is not a function of the nitric acid concentration in either phase, but is strongly affected by the concentration of uranium (5). The distribution coefficients of the nitric acid and of the uranium vary with changes in the T.B.P. concentration in the hydrocarbon diluent.

During continuous countercurrent extraction with such a chemical system, the driving force for uranium transfer to the organic phase would vary along the length of the extraction apparatus as the concentrations of uranium and nitric acid in the two phases varied. If the nitric acid concentration in the two phases were to stay constant, the change in the driving force for uranium would change as the result of changes in the uranium concentrations only. However, the nitric acid concentration varies also, and the determination of the driving force existing at any point in the column will be accurate only to the extent that the effect of nitric aci $d$ concentration upon uranium distribution is accounted for.

The purpose of this investigation was to determine the effect upon uranium extraction of variation in the concentration of T.B.P. in the organic phase during countercurrent extraction. The apparatus used to carry out the extraction was a pulse column. The aqueous feed contained uranyl nitrate, nitric acid and sodium nitrate. The effectiveness of the operation was measured by determining the height of a transfer unit in the pulse column.

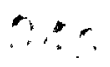


IV. PROCEDURE

The equipment used in this study is shown diagramatically in Figure $I$ and consists of two pulse columns, $12 \mathrm{ft}$. in height and having an inside diameter of 2 in. One colum, having a 2-in. plate spacing, served as the extractor, and the other column, having a plate spacing of $I$ in., was used as a stripper. The extractor contained three stainless-steel sections located between the cartridges containing the plates. These sections permitted sampling of the aqueous and organic streams during operation.

The tap sections were constructed from 4-in. pipe. A 1/4-in. tube entered the pipe from either side, and each tube was fitted with an elbow, one directed upward and the other downward (see Figure 2).

Except for the inclusion of the sampling taps and the use of a 2-in. plate spacing in the extractor, the equipment was identical to that described in the thesis of Griffith, et al (3).

The pulse columns were operated countercurrently, and the organic phase was dispersed.

Data were taken on the extractor only, the stripper serving to remove uranium from the organic stream so that it could be recycled.

As the primary purpose of the investigation was to determine the effect upon uranium extraction of variation in the concentration of $T . B . P$. in the organic phase, values were selected for other operating variables and held constant. These values may be listed as follows:

1. Feed concentration

$10 \mathrm{~g} \cdot / 1$. U [as $\left.\mathrm{UO}_{2}\left(\mathrm{NO}_{3}\right)_{2}\right]$

$1 \mathrm{M} \mathrm{HNO}$

$3.4 \mathrm{M} \mathrm{NaNO}_{3}$

2. Hydrocarbon diluent

Varsol

3. Aqueous flow rate

$475 \mathrm{ml} / \mathrm{min}$. (except for Run 7)

4. Ratio of pure T.B.P. flow to aqueous phase flow

0.06 (volume basis)

5. Pulse height

$5 / 8$ in.

6. Pulse frequency

$50 \mathrm{cycles} / \mathrm{min}$.

For each of seven runs, the concentration of T.B.P. was varied. The lowest concentration was $5 \%$ by volume ( 95 volumes of Varsol mixed with 5 volumes of pure T.B.P.), and runs were also made at $10,15,20,25$, and $30 \%$ T.B.P.

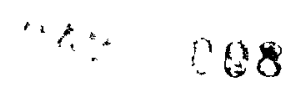




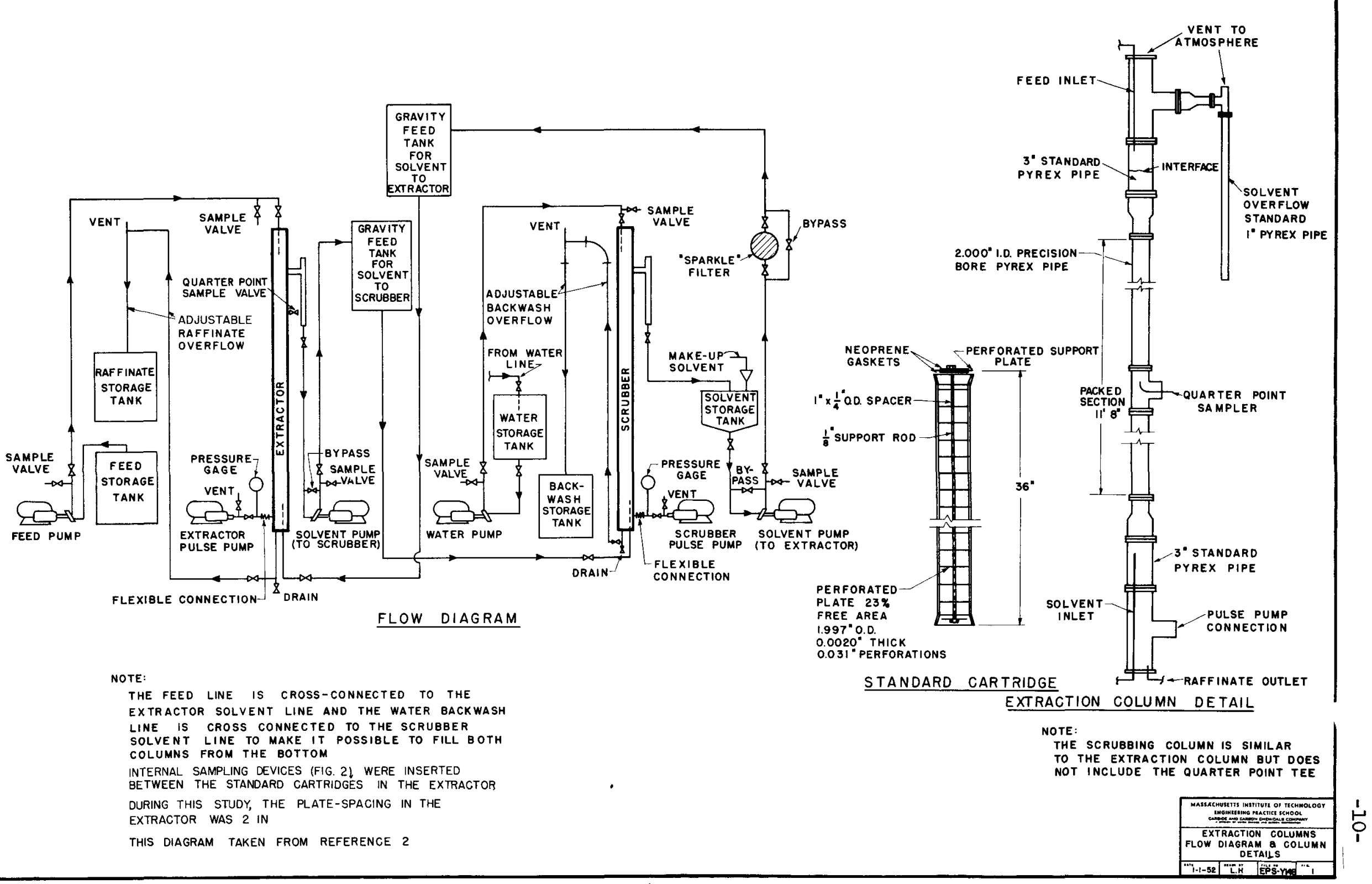



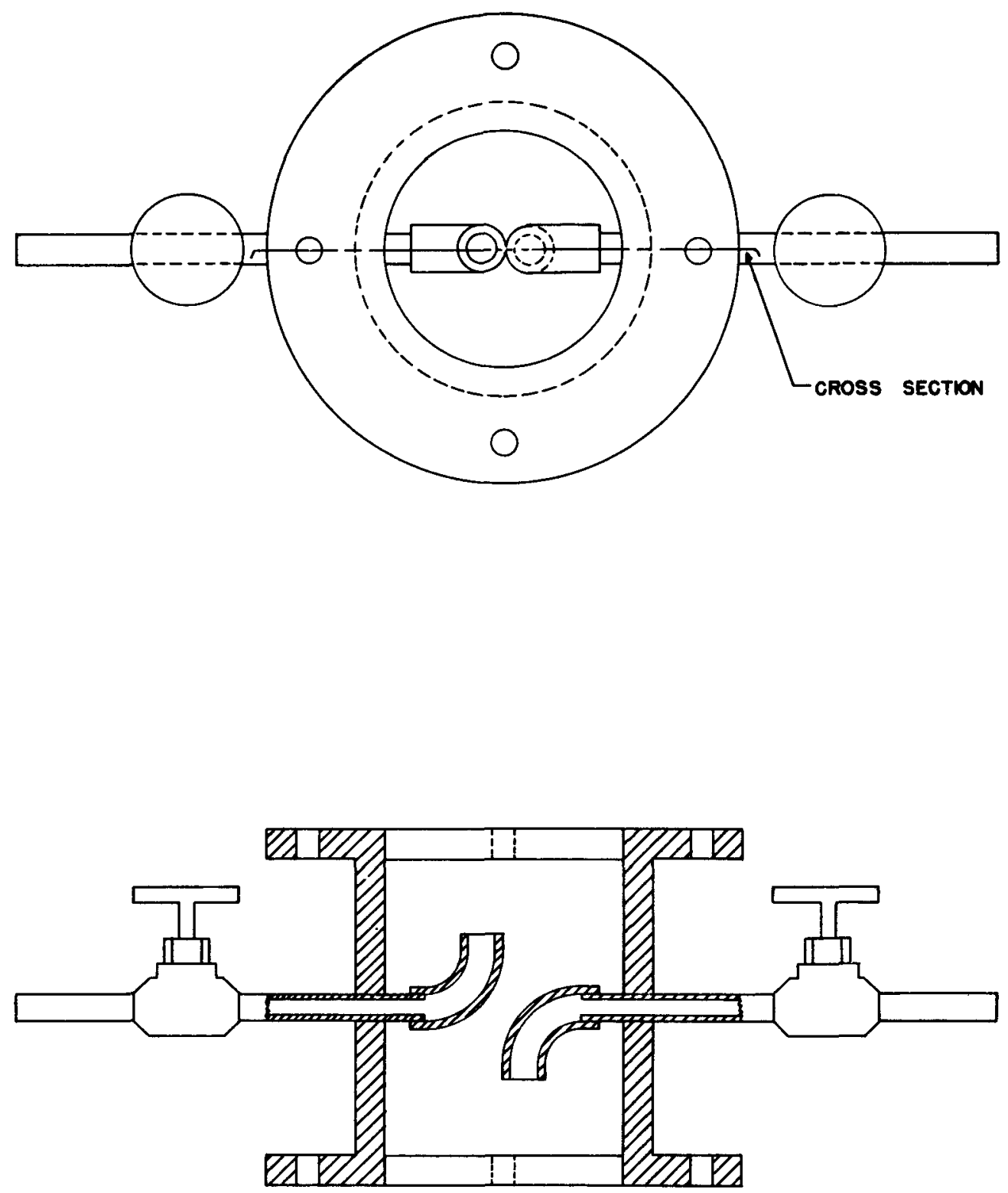

MASSACHUSETIS INSTITUTE OF TECHNOLOGY ENGINEERING PRACTICE SCHOOL CAROHOE AND CAREON CHEMICALS GDMPAN 
Equilibrium data for the system T.B.P.-in-Varsol, uranyl nitrate, nitric acid, sodium nitrate and water were taken for T.B.P.-in-Varsol concentrations of 30,20 and $10 \%$. Aqueous and organic solutions were equilibrated in separatory funnels to obtain these data. Details of the procecture used in obtaining the equilibrium data and of the analytical procedure for uranium are included in Appendix $B$.

The column was operated for 4 hours to attain. steady state. During the fifth hour samples of each phase were slowly removed from the three tap sections. In about 45 minutes, a 150-ml. sample was removed from each tap. Inlet and outlet streams were sampled at the end of the fifth hour. All samples were analyzed for nitric acid and uranium, by procedures outlined in Appendidx $B$.

\section{RESULTS}

A. URANIUM TRANSFER DATA

The results of the extraction studies are given in Figures 3 and 4 and in Table I. Figure 3 is a plot of the overall height of a transfer unit (based on the organic phase) as a function of the percent T.B.P.-in-Varsol. The number of transfer units (overall, based on the organic phase) is plotted against percent T.B.P. in Figure 4. Table I shows the values for the H.T.U. and N.T.U. obtained in each section of the column.

Figure 5 shows the experimental uranium equilibrium data.

Figure 6 is a plot of the operating and equilibrium lines for a typical run (Run 6, 10\% T.B.P.). The dashed lines represent the equilibrium lines for various constant nitric acid concentrations which were calculated from available Hanford data (2). A solid line has been drawn through these lines to show the equilibrium line which would apply to the pulse column as operated. The solid line crosses the dashed line because nitric acid transfer occurs in the column. 


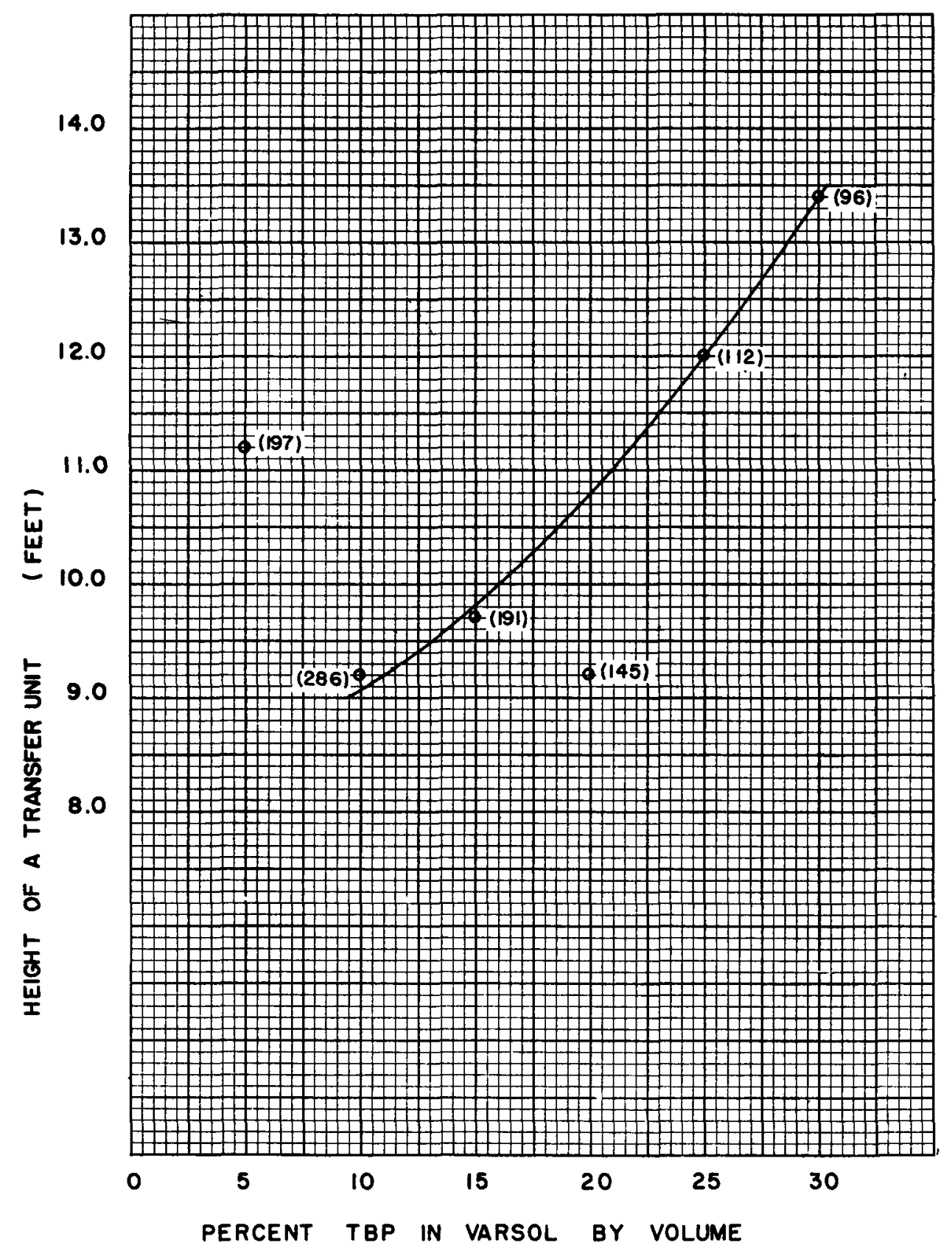

NUMBERS IN PARENTHESES REPRESENT

ORGANIC FLOW RATES (T.B.P O VARSOL)

IN ML./MIN.

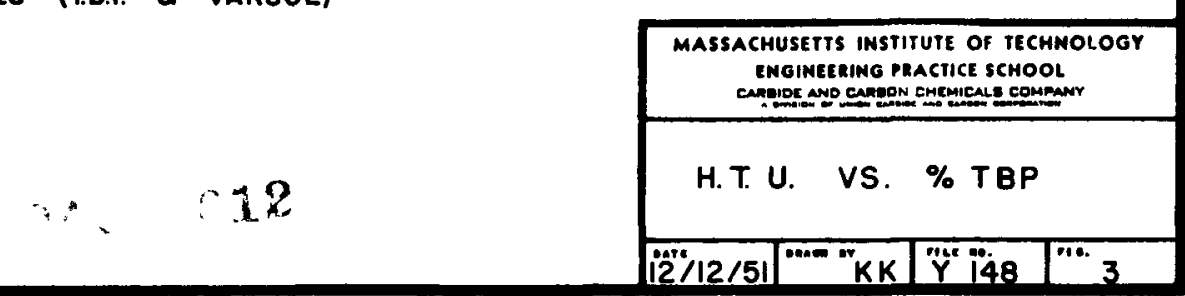




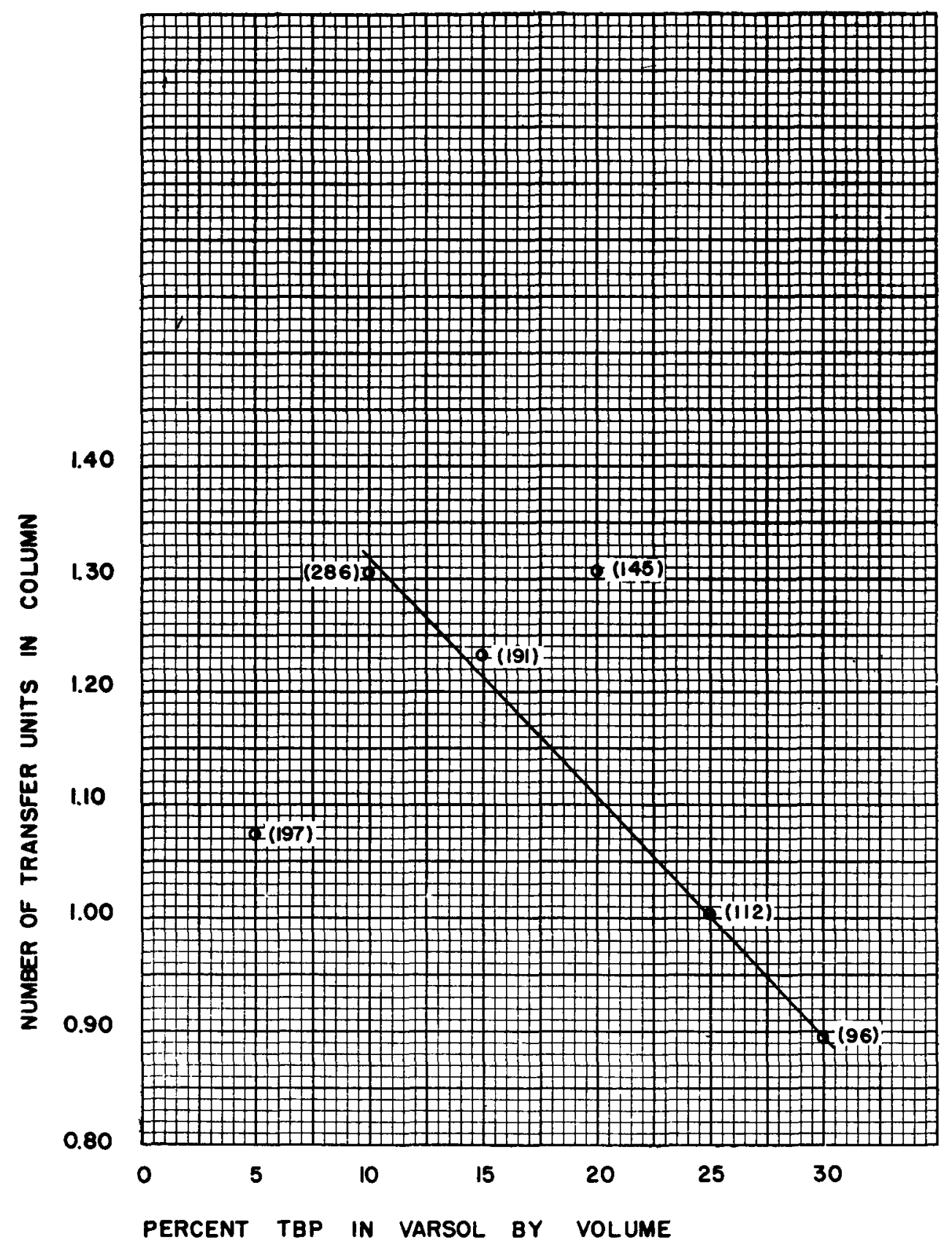

NUMBERS IN PARENTHESES REPRESENT

ORGANIC FLOW RATES (T.B.P O VARSOL)

IN ML/MIN.

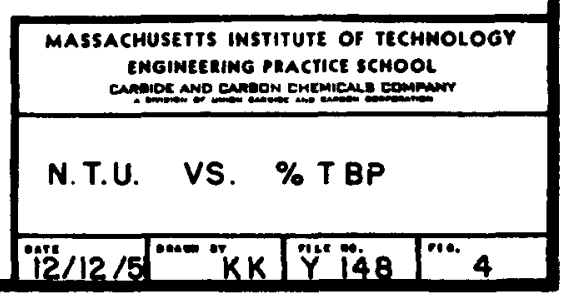

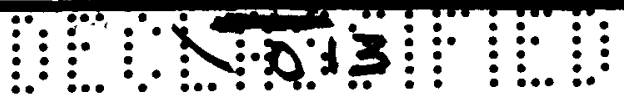


TABLE I

\section{VALUES FOR H.T.U.OE AND N.T.U.OE}

\begin{tabular}{|c|c|c|c|c|c|c|c|c|}
\hline $\begin{array}{l}\text { Run } \\
\text { No. }\end{array}$ & Volume & $\begin{array}{l}\text { Organic } \\
\text { Rate }\end{array}$ & & $\begin{array}{c}\text { Top } \\
\text { Section }\end{array}$ & $\begin{array}{l}\text { Upper } \\
\text { Middle } \\
\text { Section }\end{array}$ & $\begin{array}{l}\text { Lower } \\
\text { Middle } \\
\text { Section }\end{array}$ & $\begin{array}{l}\text { Bot tom } \\
\text { Section }\end{array}$ & $\begin{array}{l}\text { Entire } \\
\text { Column }\end{array}$ \\
\hline & $\not$ T.B.P. & $\mathrm{ml} . / \min$. & & & & & & \\
\hline 1 & 30 & 96 & $\begin{array}{l}H_{0} T_{0} U_{0}\left(f t_{0}\right) \\
\text { N.T.U. }\end{array}$ & $\begin{array}{l}6.20 \\
0.4840\end{array}$ & $\begin{array}{l}16.0 \\
0.188\end{array}$ & $\begin{array}{l}27.3 \\
0.1098\end{array}$ & $\begin{array}{l}26.4 \\
0.1135\end{array}$ & $\begin{array}{l}13.4 \\
0.895\end{array}$ \\
\hline 2 & 25 & 112 & $\begin{array}{l}H_{0} T_{0} U_{0}(f t .) \\
\text { N.T.U. }\end{array}$ & $\begin{array}{l}5.52 \\
0.5437\end{array}$ & $\begin{array}{l}13.1 \\
0.2290\end{array}$ & $\begin{array}{l}23.6 \\
0.1271\end{array}$ & $\begin{array}{l}29.4 \\
0.102\end{array}$ & $\begin{array}{l}12.0 \\
1.002\end{array}$ \\
\hline 3 & 20 & 145 & $\begin{array}{l}H_{0} T_{0} U_{0}\left(f t t_{0}\right) \\
N_{0} T_{0} U_{0}\end{array}$ & $\begin{array}{l}5.80 \\
0.5161\end{array}$ & $\begin{array}{l}6.82 \\
0.4397\end{array}$ & $\begin{array}{l}26.1 \\
0.115\end{array}$ & $\begin{array}{l}12.7 \\
0.237\end{array}$ & $\begin{array}{l}9.2 \\
1.308\end{array}$ \\
\hline 4 & 15 & 191 & $\begin{array}{l}H_{0} T_{.} U_{0} \\
\text { N.T.U. }\left(f t_{0}\right)\end{array}$ & $\begin{array}{l}4.98 \\
0.6032\end{array}$ & $\begin{array}{l}11.6 \\
0.2578\end{array}$ & $\begin{array}{c}19.2 \\
0.156\end{array}$ & $\begin{array}{l}13.9 \\
0.216\end{array}$ & $\begin{array}{l}9.7 \\
1.233\end{array}$ \\
\hline 6 & 10 & 286 & $\begin{array}{l}\text { H.T.U. (ft. ) } \\
\text { N.T.U. }\end{array}$ & $\begin{array}{l}3.44 \\
0.8714\end{array}$ & $\begin{array}{l}9.68 \\
0.3101\end{array}$ & $\begin{array}{l}36.2 \\
0.0828\end{array}$ & $\begin{array}{l}70.6 \\
0.0425\end{array}$ & $\begin{array}{l}9.2 \\
1.307\end{array}$ \\
\hline 7 & 5 & 197 & $\begin{array}{l}\text { H.T.U. }\left(f t_{\bullet}\right) \\
\text { N.T.U. }\end{array}$ & $\begin{array}{l}4.96 \\
0.6048\end{array}$ & $\begin{array}{l}20.1 \\
0.1492\end{array}$ & $\begin{array}{l}22.2 \\
0.135\end{array}$ & $\begin{array}{l}16.3 \\
0.184\end{array}$ & $\begin{array}{l}11.2 \\
1.073\end{array}$ \\
\hline
\end{tabular}

Note: Run 5 was discontinued because of unstable flow conditions. 
16

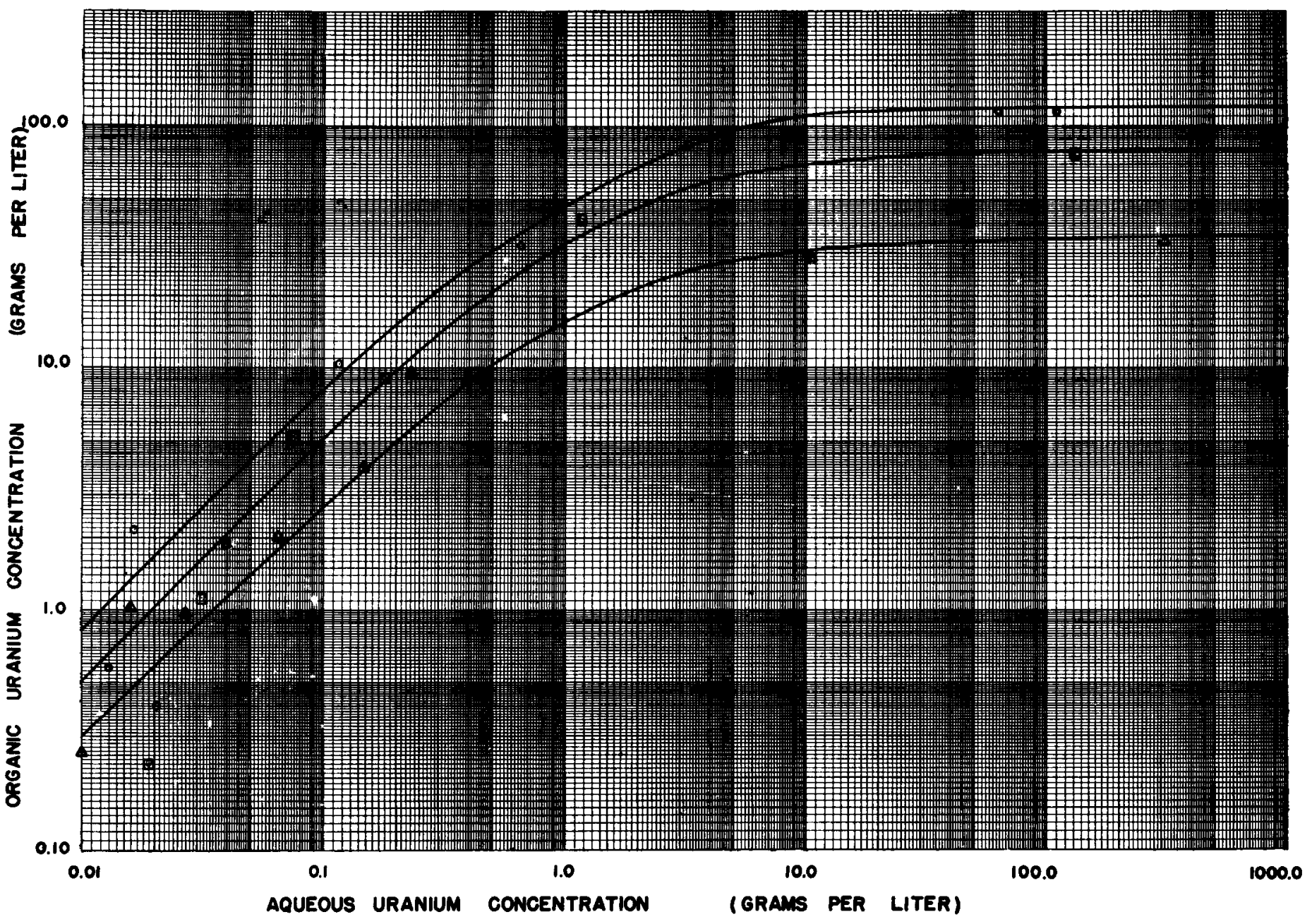

SYSTEM:

UO, (NO, IN 3.4 MOLAR NONO AND 1.0 MOLAR HNO - AQUEOUS PHASE TRIBUTYL PHOSPHATE IN VARSOL - organic PHASE

- $30 \%$ TBP, $\triangle 20 \%$ TBP, $\triangle 10 \%$ TBP

\begin{tabular}{|c|c|}
\hline \multicolumn{2}{|c|}{ 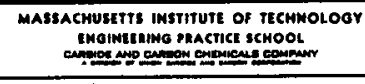 } \\
\hline EXPERIME & ITAL \\
\hline EQUILBRIUM & DATA \\
\hline
\end{tabular}




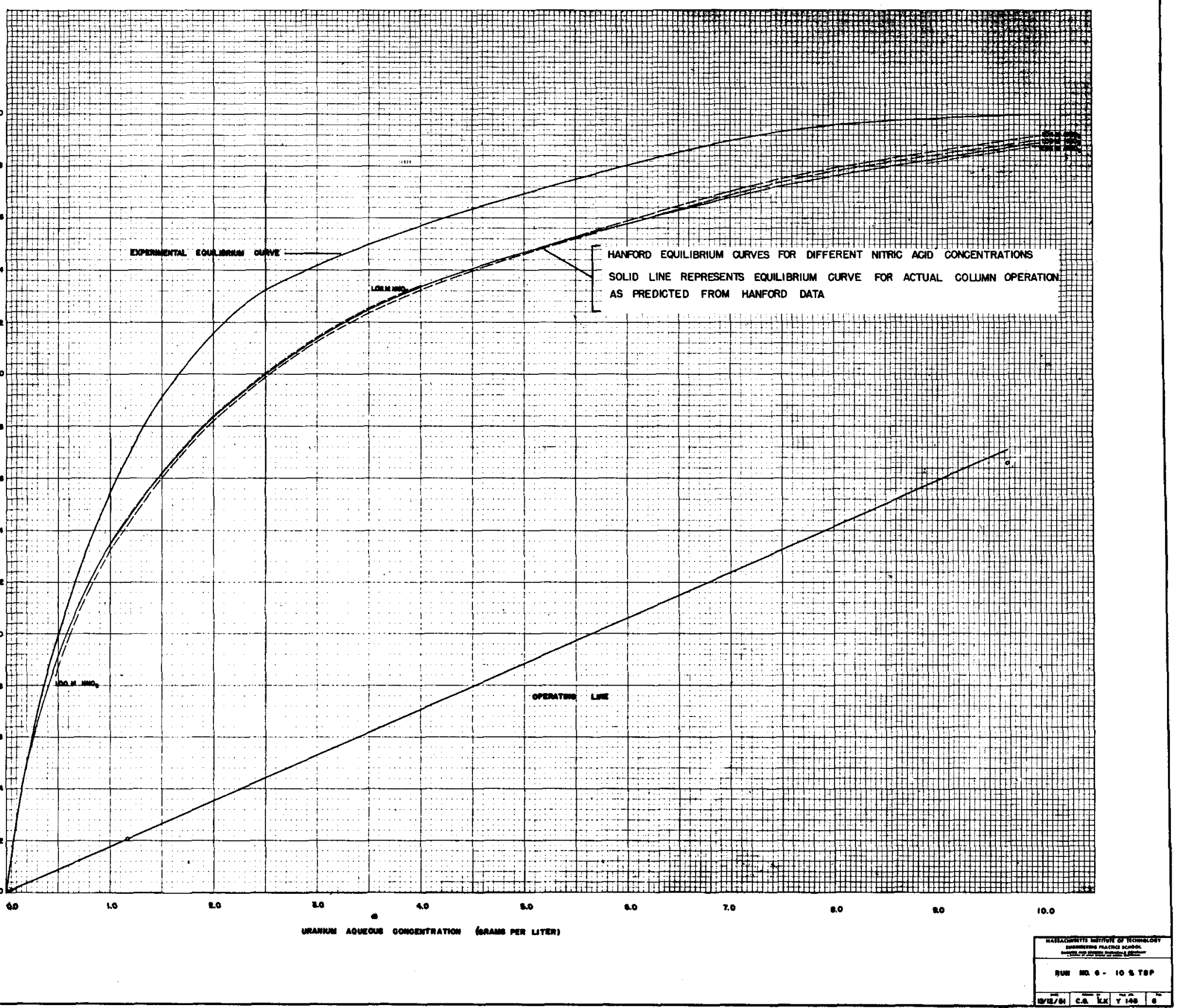




\section{B. NITRIC ACID TRANSFER DATA}

In Figure 7 a plot is presented of the operating line for nitric acid obtained for Run 1. Also shown is an equilibrium line, which has been estimated on the basis of arbitrarily selected calculational steps. The method of calculation is explained in Appendix C.

The points indicated by circles are experimental data points, obtained by the analysis of the samples taken from the column during operation. In two cases the experimental operating points were some distance from the operating line indicated by the other points. An error in the analysis of the aqueous sample was assumed to account for the discrepancy, and two points, represented by triangles, were drawn on the operating line to enable calculation of the points for the equilibrium lines.

The points indicated by squares are the calculated equilibrium points for Run 1.

The numbers beside each data point indicate the position in the column at which the analyses were made. In the case of the equilibrium line (calculated), the numbers identify the point on the operating line to which the equilibrium point applies. The sampling points were numbered from the top to the bottom of the column, i.e., Point $I$ on the operating line indicates the nitric acid concentration in the streams at the top of the column, Point 2, the concentration at the first sample tap from the top of the column, and so on.

Figure 8 shows the equilibrium distribution coefficient as a function of the initial uranium concentration in the aqueous phase. The distribution coefficient is defined as the ratio of the organic nitric acid concentration to the aqueous nitric acid concentration. A known volume of organic was equilibrated with an equal volume of an aqueous solution containing a known amount of uranium and nitric acid.

The curves in Figure 8 which are drawn through solid circles show the data points obtained experimentally. Those which pass through outline circles were estimated by constructing cross-plots of the distribution coefficient as a function of T.B.P. concentration for various values of constant initial aqueous uranium concentration. 


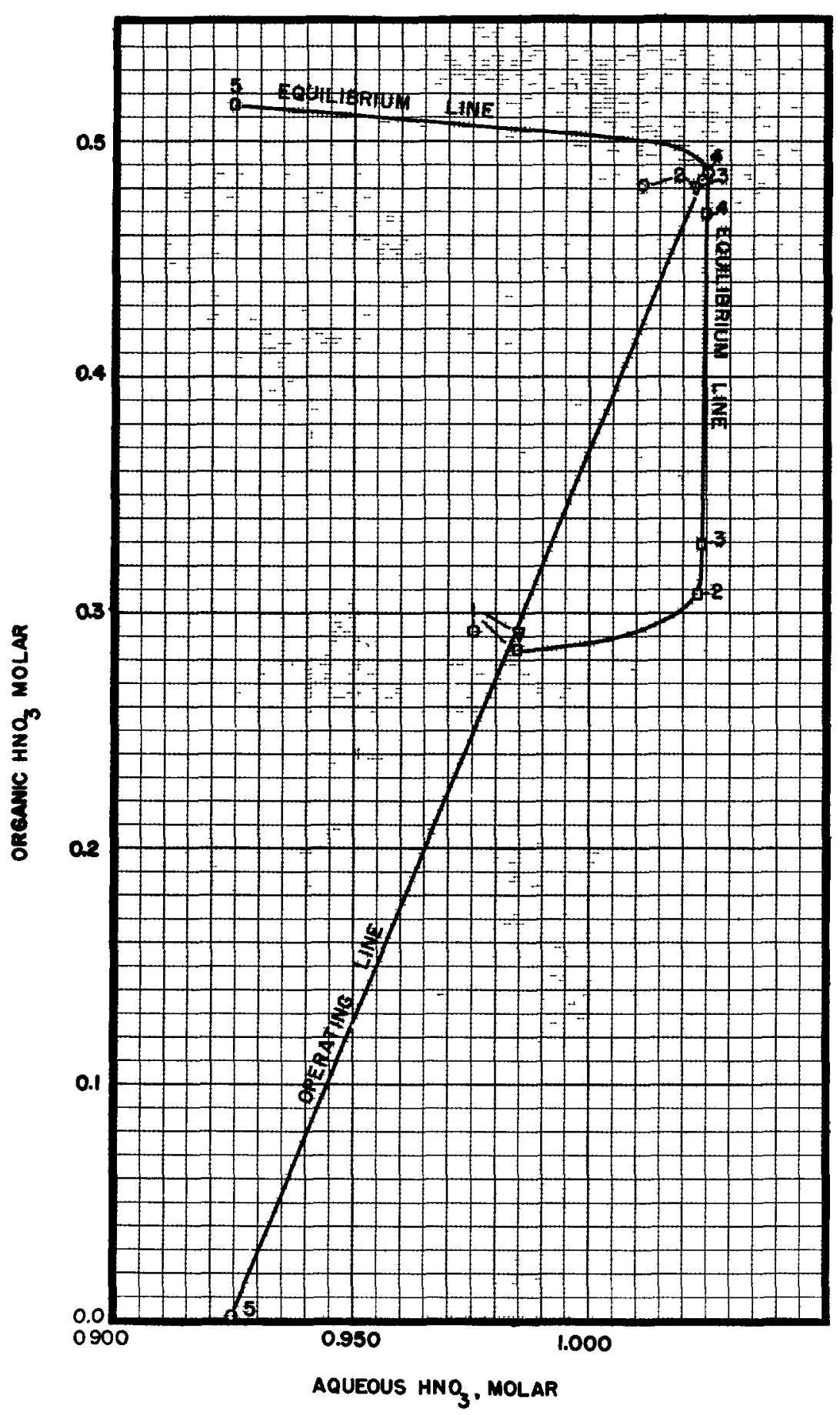




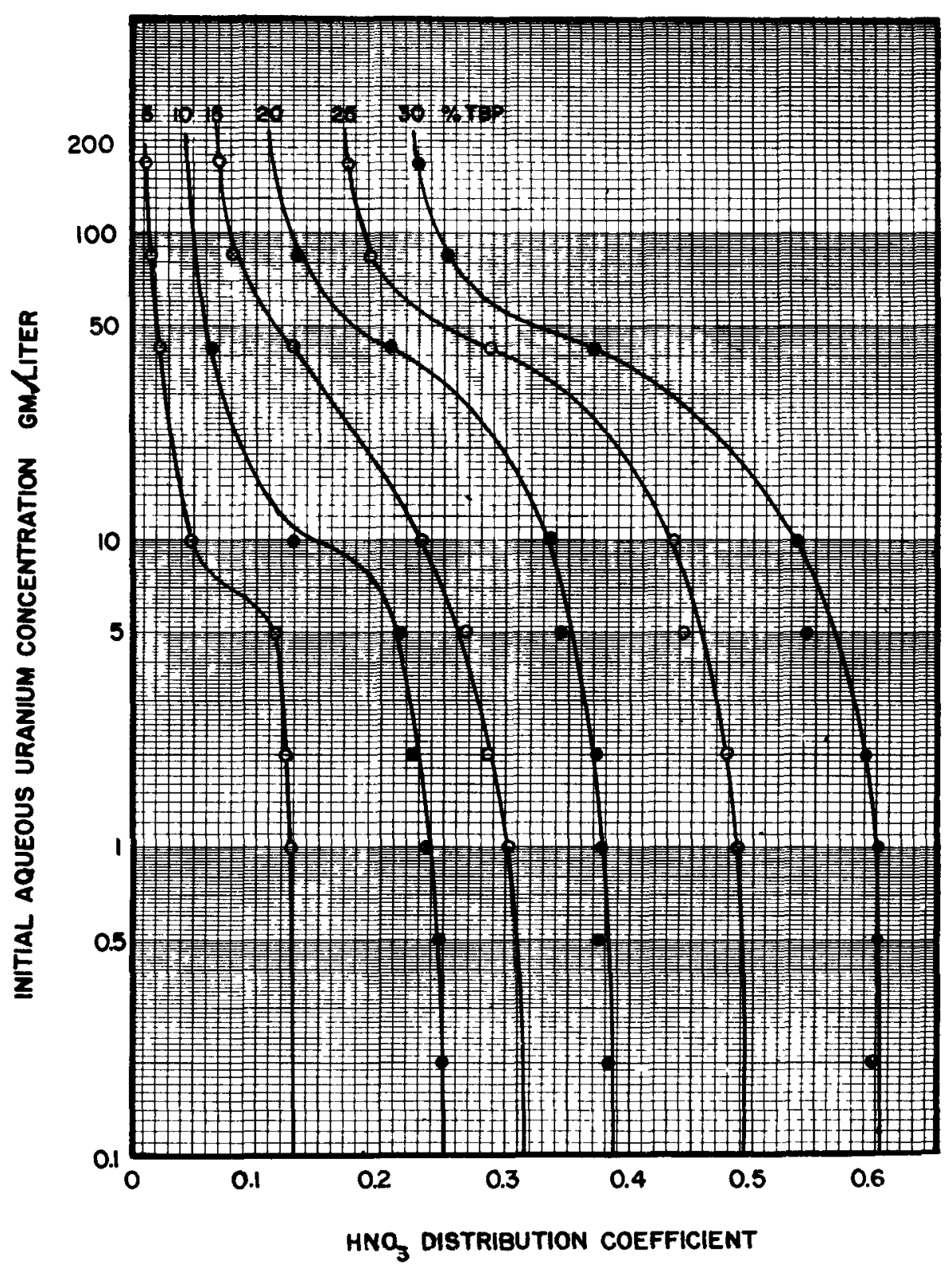

- POINTS FROM EXPERIMENTAL DATA

- POINTS FROM CROSSPLOT OF EXPERIMENTAL DATA

\begin{tabular}{|c|}
\hline 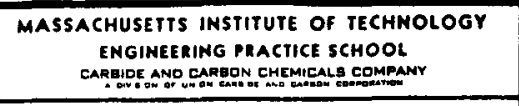 \\
\hline $\begin{array}{l}\text { EFFECT OF URANIUM ON } \\
\text { NITRIC ACID DISTRIBUTION }\end{array}$ \\
\hline
\end{tabular}

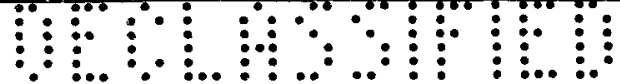


VI. DISCUSSION OF RESULTS

A. URANIUM EXTRACTION

Figure 3 shows that the height of a transfer unit increases as the percent T.B.P.-in-Varsol increases. The ratio of the flow of T.B.P. to the flow of aqueous solution was maintained at a constant value during all runs. Except for Run 7 (at 5\% T.B.P.) the aqueous flow rate was held constant at $475 \mathrm{ml} . / \mathrm{min}$. (within $5 \mathrm{ml} / \mathrm{min}_{\text {. }}$ ). As a consequence, the direction of increasing percent T.B.P. in Figures 3 and 4 is also the direction of decreasing flow rate. The value of organic flow rate for each experimental data point is shown on the plots.

The height of a transfer unit is related to the flow rates and the equilibrium line by means of the following equations (ㅁ):

$$
\begin{aligned}
& H \cdot T \cdot U \cdot O E=H \cdot T \cdot U \cdot E+\frac{m E}{R}(H \cdot T \cdot U \cdot R)
\end{aligned}
$$

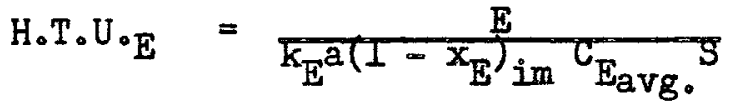

$$
\begin{aligned}
& H \cdot T \cdot U \cdot R=\frac{R}{k_{R} a\left(1-x_{R}\right)_{i m} C_{R_{a v g}} S}
\end{aligned}
$$

The assumptions implicit in the derivation of these equations (6) are sufficiently far removed from the conditions existing during this investigation so that their quantitative use is precluded. However they serve as a basis for a qualitative discussion of the trends shown in Figures 3 and 4.

The following assumptions are made:

1. Although the slope of the equilibrium line, $m$, is not constant, the average slope over the range in concentrations which characterized the six runs described in this report is nearly the same for each run. This is a fair assumption, since the change in conconcentration over the length of the column is about the same for each run, and the shape of the equilibrium curve is nearly the same for each run (although they are displaced from each other somewhat).

2. The terms $\left(1-x_{R}\right)_{i m},\left(1-x_{E}\right)_{i m}, k_{E}, k_{R}, C_{E_{a v g}}$, and $C_{R_{a v g}}$ do not change from run to run to the same extent that the flow rate changes.

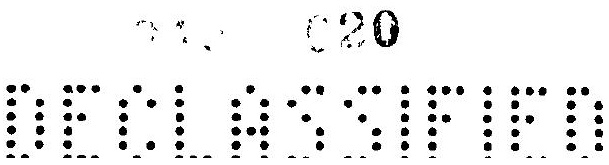


Because the cross-sectional area of the colum and the aqueous flow rate, $R$, are constant, changes in interfacial area and in the organic flow rate should account for most of the changes observed in the values of H.T.U.OE. A decrease in the value of $\mathrm{E}$ will cause a decrease in H.T.U.OE because of a decrease in the value for H.T.U.E, as shown by Equation 2, and also because of a decrease in the term $\frac{m}{K}$. A decrease in the interfacial area, $a$, has the opposite effect. The curves for $H_{\circ} T \cdot U \cdot O E$ appear to show that the interfacial area in the column decreases as flow rate decreases. This is supported by the fact that a smaller average bubble size was observed in the column during operation at high values of $T . B . P$. concentration, i.e. at lower organic flow rates. A decrease in interfacial area would also result if the hold-up of organic in the column were to decrease with decreasing flow rates.

The data point for Run 7 (5\% T.B.P.) is quite far from the curves in Figures 3 and 4. This may be the result of changes in both flow rates. Flooding in the stripper made operation of the stripper at a reduced aqueous flow rate necessary in order to maintain the constant ratio of aqueous flow to pure T.B.P. flow. In this case both flow rates, $E$ and $R$, have been decreased by comparis on with Run 6 (10\% T.B.P.). It seems likely that the decrease in the flow rates more than balanced the decrease in interfacial area for this run and accounted for a decrease in the value of H.T.U.OE.

Table I shows that, in general, the H.T.U. computed for various sections of the column is mach less at the top of the tower than at the bottom. This fact is believed to result from marked differences in the value of the slope of the equilibrium line for various sections in the column. Figure 5 shows that the slope of the equilibrium line near the tor of the column (corresponding to high uranium concentration) is much less than it is near the bottom of the column. Thus an increase in the value of H.T.U. OE would be expected if the change in the value $\mathrm{m}$ down the column were large by comparison with changes in the other terms of Equations 1,2 , and 3 .

\section{B. EQUILIBRIUM DATA}

The data points for uranium equilibrium distribution are close to the curves which have been drawn in Figure 5 except for those taken at low concentrations. The deviation exhibited in this range is felt to be the result of inaccuracies in the analysis. Methods of analysis are described in Appendix B. From the equilibrium data available (2), equilibrium lines were calculated for various nitric acid concentrations (Figure 6). These lines fall below the line which was obtained from experimental data. The effect of nitric acid concentration upon the position of the equilibrium line is shown by the Hanford data to be too small. Because the change in nitric acid concentration in the pulse column varied only from 1.1 to 0.92 
mole/1. in the aqueous phase, the effect upon the uranium distribution of this change in nitric acid concentration was neglected. The values presented for heights of a transfer unit were calculated using the experimental equilibrium line.

The equilibrium data for nitric acid distribution were taken at a concentration of $3.4 \mathrm{M} \mathrm{NaNO}$, so that the effect of the salt upon distribution was constant. On the basis of data presented by Moore (5), the effect of nitric acid concentration upon its own distribution coefficient was neglected. Figure 8 shows the effect of uranium concentration in the aqueous phase and of T.B.P. concentration upon the distribution of nitric acid. Figure 8 also shows that the nitric acid distribution coefficient increases with decreasing uranium concentration until a value of about $I \mathrm{~g} \cdot / \mathrm{l}_{\text {. }}$ is reached. Below this value, the nitric acid distribution coefficient is nearly constant.

\section{NITRIC ACID EXTRACTION}

Figure 7 shows typical operating and equilibrium lines for nitric acid extraction (Run I). The concentration at the top of the column, Point I, does not lie at the top of the operating line as it does for uranium, but is at a point somewhat above the middle of the operating line. The next three points, obtained from samples between the four plate sections, are close to each other and near the maximum concentration shown by the operating line. The last point, at the bottom of the colum, is at the bottom of the equilibrium line. The slope of the operating line is that wich would be predicted from the ratio of the aqueous to organic flow rates.

As the organic enters the column, it is free of uranium and nitric acid, so that both componenets are transferred to the organic phase. As the organic progresses up the colum, the distribution coefficient for nitric acid becomes less as more uranium is transferred to the organic phase. At some point an equilibrium condition is reached and the transfer of nitric acid stops. Near the top of the column the uranium concentration in the organic phase becomes great enough so that nitric acid is transferred back into the aqueous phase. The positions of Points 2, 3 , and 4 indicate that little transfer of nitric acid occurs in either direction in the two middle sections of the column.

Using a method described in Appendix $C$, an equilibrium line for this process has been estimated. The points calculated for this line are shown as squares and indicate that the equilibrium line loops around the top of the operating line so that both extraction and stripping of the nitric acid can occur in different sections of the same column.

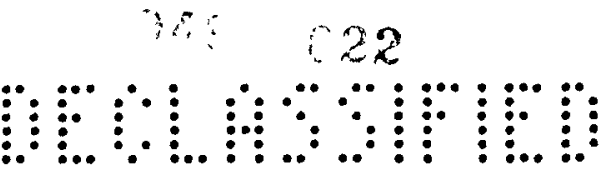




\section{CONCLUSIONS}

The following conclusions are based upon the results of this investigation and are intended to apply only to the conditions which have been described herein:

1. In the extraction of uranyl nitrate from an aqueous solution containing nitric acid and sodium nitrate, with an organic solution of tributyl phosphate in Varsol, the value of the height of a transfer unit (overall, based on the organic phase) was found to increase with increasing T.B.P. concentration.

2. The increase of H.T.U.OE may be explained on the basis of changes in organic flow rate, since the rat1o of the flow rate of pure T.B.P. to aqueous flow rate was held constant.

3. When the nitric acid concentration in the aqueous phase is near IM, the amount of acid transferring to the organic phase over the length of the column is relatively small.

4. Equilibrium data over the range of concentrations used in this investigation are presented.

\section{RECOMMENDATIONS}

1. The range of data covered in this investigation should be extended to cover other organic flow rates and T.B.P. concentrations.

2. Data on maximum throughput capacity should be taken. 
IX. APPENDIX

A. SUMMARY OF DATA AND CALCULATED VALUES

TABLE II

OPERATING CONDITIONS

\begin{tabular}{|c|c|c|c|c|c|c|}
\hline \multirow[t]{2}{*}{$\begin{array}{l}\text { Run } \\
\text { No. }\end{array}$} & $\begin{array}{l}\text { T.B.P. } \\
\text { Conc. }\end{array}$ & $\begin{array}{c}\text { Time } \\
\text { of Run }\end{array}$ & $\begin{array}{l}\text { Ratio of Pure } \\
\text { T.B.P. Flow } \\
\text { Rate to Aqueous } \\
\text { Flow Rate } \\
\end{array}$ & \multicolumn{3}{|c|}{ Flow Rates } \\
\hline & Volume $\%$ & $\mathrm{hr}$. & (volumetric) & $\begin{array}{l}\text { Aqueous } \\
\text { Extractor }\end{array}$ & $\begin{array}{l}\text { ml./min. } \\
\text { Aqueous } \\
\text { Stripper }\end{array}$ & $\begin{array}{l}\text { Organic } \\
\text { Stripper } \\
\text { Extractor }\end{array}$ \\
\hline 1 & 30 & 5.00 & 0.0608 & 475 & 194 & 96.3 \\
\hline 2 & 25 & 4.84 & 0.0585 & 478 & 195 & 112 \\
\hline 3 & 20 & 5.33 & 0.0611 & 475 & 738 & 145 \\
\hline 4 & 15 & 5.00 & 0.0599 & 478 & 745 & 191 \\
\hline 6 & 10 & 5.00 & 0.0608 & 470 & 277 & 286 \\
\hline 7 & 5 & 8.50 & 0.0630 & 160 & 267 & 197 \\
\hline
\end{tabular}

Note: Run 5 was discontinued because of unstable flow conditions.

S 
TABLE III

\section{SURYARY OF AQUDOUS CONCENTRATIONS IN EXTRACTOR}

Bun

1 g. U/1. mole $\mathrm{HNO}_{3} / 1$.

2 g. $\mathrm{U} / \mathrm{l}$. mole $\mathrm{HNO}_{3} / 1$.

3 g. $0 / 1$. mole $\mathrm{HNO}_{3} / 1$.

4 g. U/l. mole $\mathrm{HNO}_{3} / \mathrm{l}$.

6 g. $0 / 1$. mole $\mathrm{HNO}_{3} / 1$.

9.68

9.20

0.979

1.43

1.019

0.080

1.026

0.19

1.041

0.67

1.021

0.13

1.025

0.33

1.025

0.058

0.925

1.084

0.044

1.045

0.009

0.946

0.015

1.028

0.002

0.935

7 g. $0 / 1$ mole $\mathrm{HNO} / 1$.
10.03

1.074

\subsection{7}

1.050

0.060

1.068

0.042

1.112

1.104
0.027

1.067

0.002

0.976

1.34
0.020

1.108
0.002

0.997 
TABLE IV

\section{SUMMARY OF ORGANIC CONCENTRATIONS IN EXTRACTOR}

Run Top Top Tap Middle Tap Bottom Tap Bottom

1 g. $\mathrm{U} / \mathrm{l}$. mole $\mathrm{HNO}_{3} / 1$.

48.6

0.293

15.9

0.481

4. 53

0.484

1.40

0.487

0.039

0.002

2. g. $\mathrm{U} / \mathrm{l}$.

mole $\mathrm{HNO}_{3} / \mathrm{I}$

41.9

0.288

12.7

0.361

2.72

0.396

0.60

0.408

0.121

0.0025

3

g. U/l.
mole $\mathrm{HNO}_{3} / 1$.

35.4

0.235

5.51

0.319

0.60

0.364

0.217

0.010

0.338

0.002

4 g. $U / 1$. mole $\mathrm{HNO}_{3} / \mathrm{I}$.

24.0
0.16

3.39

0.28

0.256

0.055

0.249

0.003

0.0021

6 g. $U / 1$.

16.6 mole $\mathrm{HNO}_{3} / I$.

0.130

2.07

0.173

0.170

0.019

0.170

0.010

0.0032

7 g. $U / 1$

mole $\mathrm{HNO}_{3} / \mathrm{I}$.

6.49

0.0807

1.32
0.0841

0.080

0.0830

0.012

0.0830

0.031

0.002 


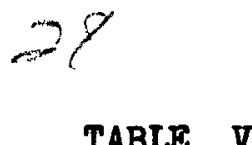

RESULTS OF MATERIAL BALANCE CALCULATIONS ON EXTRACTOR

Run

\begin{tabular}{cccc}
\multicolumn{4}{c}{ Uran i u m } \\
\hline $\begin{array}{c}\text { Lost By } \\
\text { Aqueous Stream }\end{array}$ & $\begin{array}{c}\text { Gained By } \\
\text { Organic Stream }\end{array}$ & $\begin{array}{c}\text { Total } \\
\text { Entering }\end{array}$ & $\begin{array}{c}\text { Total } \\
\text { Leaving }\end{array}$ \\
$\mathrm{g} / \mathrm{min}$. & $\mathrm{g} / \mathrm{min}$. & $\mathrm{g} / \mathrm{min}$. & $\mathrm{g} \cdot / \mathrm{min}$.
\end{tabular}

1

2

3

4

6

7
4.45

4.61

4.40

4.40

4. 55

1.60

1.28

5.13

4.58

4.75
4.45

4.25

$4.61 \quad 4.35$

4.40

4.85

$4.40 \quad 4.95$

4.55

$4 \cdot 70$

$1.60 \quad 1.97$

0.0244

0.0319

0.0280

0.0338

0.0211

0.0319

0.00376

0.0363

0.0123

0.0156

Note: Run 5 was discontinued because of unstable flow conditions. 


\section{B. DETERMINAT ION OF DISTRIBUTION COEFF ICIENTS}

(METHODS OF ANALYSIS)

In order to extend the equilibrium data avallable for the system T.B.P.-inVarsol, uranyl nitrate, nitric acid, sodium nitrate, and water, equilibrium determinations were made at varying uranium and nitric acid concentrations.

Forty $\mathrm{ml}$. of an aqueous solution containing known amounts of uranium, nitric acid, and sodium nitrate were equilibrated with $40 \mathrm{ml}$. of an or ganic solution of T.B.P.-in-Varsol having the proper concentration of T.B.P. The uranium concentration in each aqueous sample varied by ten-fold from that in the preceeding sample. Equilibration was carried out in separatory funnels by shaking the two phases vigorously several times, allowing coalescence to occur between periods of shaking.

Samples of each phase were then withdrawn for analysis.

1. Uranium Analysis (1)

A 10-ml. sample of the organic phase was extracted twice with 5-ml. portions of a concentrated solution of ammonium carbonate. The carbonate formed a complex with the uranium and separated it from the organic phase. Five $\mathrm{ml}$. of concentrated $\mathrm{HNO}_{3}$ and $5 \mathrm{ml}$. of concentrated $\mathrm{HClO}_{4}$ were added to the $10 \mathrm{ml}$. of the solution of uranium-carbonate complex and also to 10 ml. of the aqueous phase from the equilibration step. The solutions were then heated to dryness and redissolved in nitric acid.

Five ml. of a buffer solution were pipetted into each uranium solution. The buffer was made up by mixing $79 \mathrm{~g} \cdot \mathrm{NH}_{4} \mathrm{C}_{2} \mathrm{H}_{3} \mathrm{O}_{2}, 40 \mathrm{ml}$. of pyridine, and $20 \mathrm{ml}$. of glacial acetic acid; diluting the mixture to 1 liter; and filt ering.

Ten $\mathrm{ml}$. of ascorbic acid reagent were then added. The reagent was prepared by dissolving ascorbic acid in water, decolorizing it with $1 / 4$ g. of Norite A, and filtering. (The prepared solution is not stable for over 24 hours even under refrigeration.)

The $\mathrm{pH}$ of the sample was adjusted to between 4.5 and 4.6 with $1: 1$ anmonium hydroxide and the solution diluted to $50 \mathrm{ml}$. in a volumetric flask, using distilled water.

The optical density was measured at 410 millimicrons on a Beckman model B Spectrophotometer, using distilled water in the reference celi. A calibration curve was prepared using a solution of known uranium concentration (prepared from standard uranium black oxide). The uranium present in the sample was then read as a function of the optical density from the calibration curve.

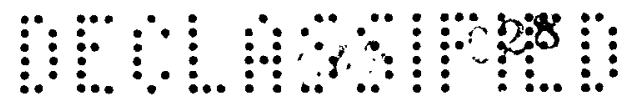




\section{Nitric Acid Analysis}

Five ml. aqueous samples from the equilibration step were diluted to $50 \mathrm{ml}$. With distilled water. They were then titrated with standard sodium hydroxide to the $\mathrm{pH}$ that corresponded to the uranium concentration which had been determined for the sample. Thus, the nitric acid analyses were dependent upon the results of the uranium analyses. A curve of pH for various aqueous uranium concentrations in the presence of $3.4 \mathrm{M} \mathrm{NaNO}_{3}$ was prepared by determining the $\mathrm{pH}$ of solutions of known uranium concentration. The curve for $0.34 \mathrm{M} \mathrm{NaNO}$ (which was present in the analyzed samples after dilution) was obtained by interpolation. The experimentally obtained curves are shown in Figure 9.

A 10-ml. sample of the organic solution from the equilibration step was added to $100 \mathrm{ml}$. of distilled water. The two phases were titrated with standard sodium hydroxide until the proper $\mathrm{pH}$ in the aqueous phase was obtained. The $\mathrm{pH}$ for this solution was taken from the curve of Figure 10 for pure uranyl nit rate solution. No sodium nitrate was considered to have transferred to the organic phase during the initial equilibration.

The amount of base added in these titrations was taken to be equivalent to the nitric acid present in the original sample.

\section{ESTIMATION OF EQUILIBRIUM LINE FOR NITRIC ACID TRANSFER}

An equilibrium point for nitric acid was calculated from the five known operating points in the column. For each point, the following method was used:

1. From the uranium equilibrium data (Figure 5), the equilibrium aqueous uranium concentration corresponding to the organic uranium concentration existing at the point was found.

2. The aqueous uranium concentration obtained in Step 1 was added to the organic uranium concentration existing in the column at the point in question. This gave the intial aqueous uranium concentration which would have been used (if, as was the case in these experiments, equal volume of organic and aqueous phases were equilibrated) to give the organic uranium concentration existing at the point.

3. Using the value for initial aqueous uranium concentration obtained from Step 2, Figure 8 was used to find the nitric acid distribution coefficient. 


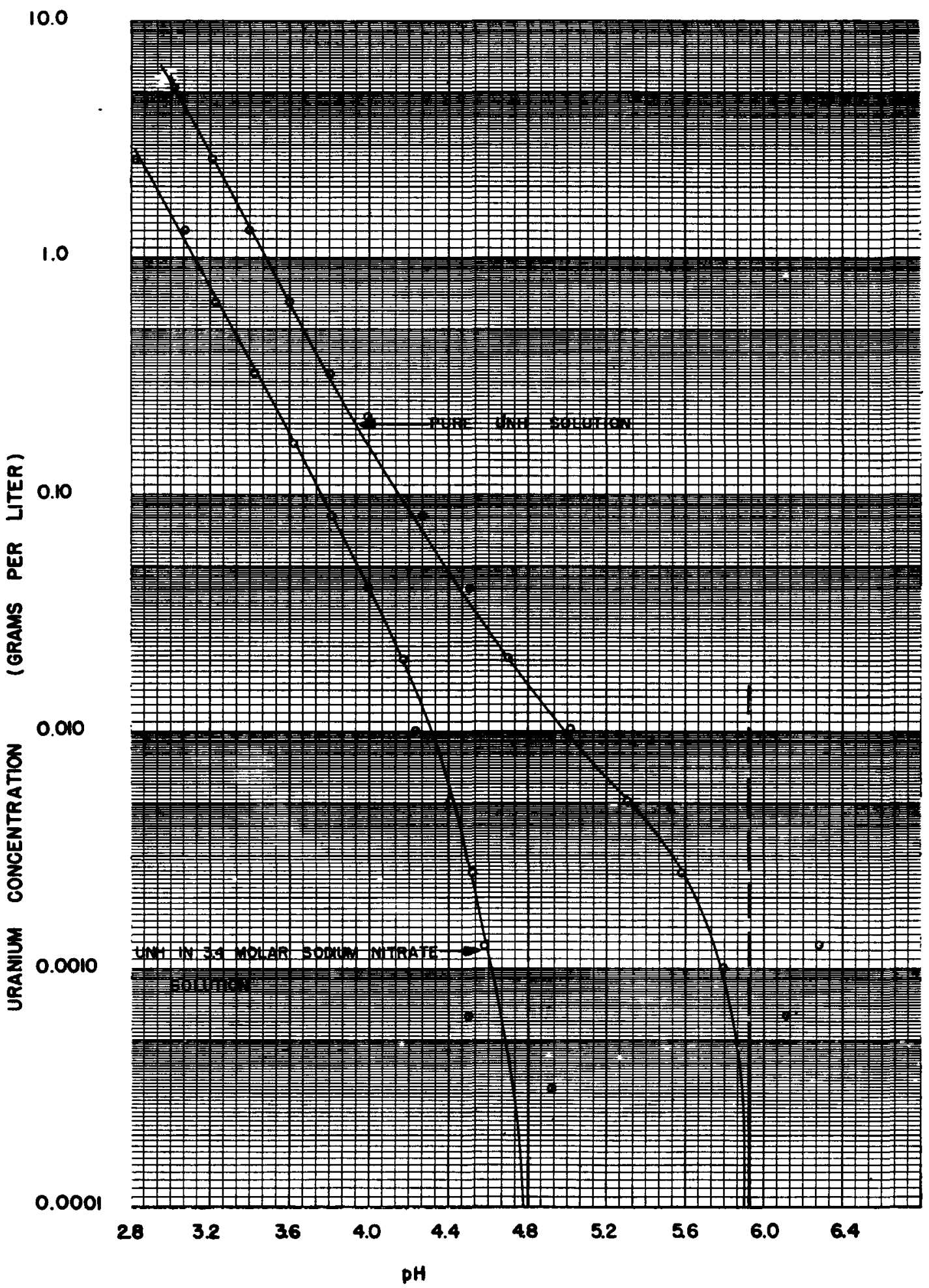


4. The equilibrium organic nitric acid concentration corresponding to the aqueous nitric acid concentration existing at the point under consideration was found by multiplying the aqueous nitric acid concentration by the distribution coefficient.

It is evident that other courses of action might have been followed in Steps 1 and 4. That is, the uranium equilibrium concentration in the organic phase might have been determined from the existing aqueous uranium concentration in Step 1 , and the equilibrium aqueous nitric acid concentration corresponding to the organic nitric acid concentration existing at the point might have been calculated in Step 4 by dividing the existing aqueous nitric acid concentration by the distribution coefficient obtained in Step 3. The position of the equilibrium line shown in Figure 7 would have been different if either of these alternate courses of action had been followed. Figure 7 is presented to indicate the type of equilibrium curve demanded by the experimental facts, rather than to enable design calculations of an exact nature.

Three conditions must be met on the basis of the explanation offered in the Discussion of Results:

1. The equilibrium line must be above the operating line at the bottom of the colum in order for extraction into the organic phase to occur.

2. The equilibrium line must touch the top of the operating line at some point in the middle of the colum in order for the concentration driving force to change direction. That is, there must be a point in the column where the driving force is zero and that point must be the top of the operating line for conditions such as those existing in these experiments.

3. At the top of the column the equilibrium line must lie below the operating line in order for stripping of the nitric acid to occur.

The equilibrium line shown in Figure 7 satisfies these requirements. 


\section{TABLE OF NOMENCLATURE}

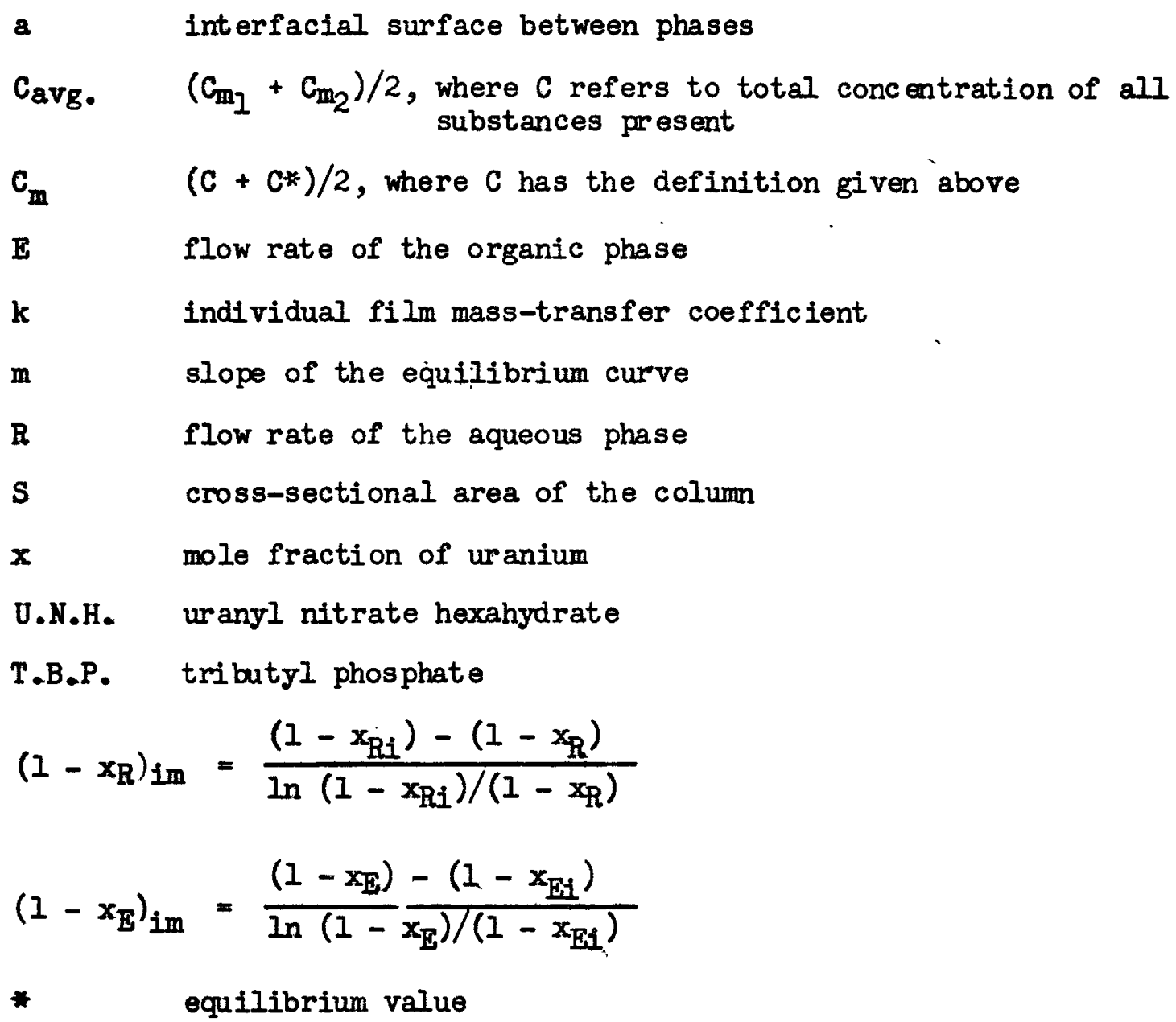

\section{Subscripts}

$\begin{array}{ll}1 & \text { refers to either phase at the top of the colum } \\ 2 & \text { refers to either phase at the bottom of the column } \\ \text { avg. } & \text { average } \\ \text { E } & \text { organic phase } \\ 1 & \text { interface } \\ \text { m } & \text { mean } \\ \text { R } & \text { aqueous phase }\end{array}$




\section{E. LITERATURE CITATIONS}

1. Barringer, Roscoe, Y-12 Plant, Personal Communication to Karl Kniel (October 18, 1951).

2. Granquist, D. P., and Merrill, E. T., "Uranium Phase Equilibria in the T.B.P. Process", General Electric, Hanford Works, HW-17747 (March 1, 1951).

3. Griffith, W. L., Jasny, G. R., and Tupper, H. T., "The Separation of Cobalt from Nickel in a Fulse Column", S.M. Thesis, Massachusetts Institute of Technology (1951).

4. Moore, R. I., "Mechanism of Extraction of Uranium by Tributyl Phosphate", U. S. Atomic Energy Conmission, AECD-3196 (June 11, 1951).

5. Moore, R. I., "The Extraction of Uranium in the Tributyl Phosphate Metal Recovery Process", Hanford Works, HW-15230 (September 1, 1949).

6. Treybal, Robert E., "Iiquid Extraction", McGraw-Hill Book Company, Inc., New York (1951).

\section{F. ACKNOWLEDGEMENTS}

The authors wish to express their thanks to Harvey Kite, Roscoe Barringer, John Cameron, and John Gregory and the operating personnel of Building $9206, \mathrm{I}-12$, for their cooperation and helpful suggestions during the course of this investigation.

\section{G. IOCATION OF ORIGINAL DATA}

The original data for this investigation are located in Data Notebooks No. 1884, pp $1-33$ and No. 1881 , pp. $3-20$, on file at the M.I.T. Practice School, Oak Ridge, Tennessee.

Karl Kniel

Clarence Gregory, Jr.

Edmund R. Renier ।

Richard H. Reuther 